\title{
SISTEM PENGAWASAN TERHADAP HAKIM KONSTITUSI DALAM MEWUJUDKAN INDEPENDENSI HAKIM
}

\author{
Eza Aulia \\ Fakultas Ilmu Sosial dan Ilmu Politik, Universitas Teuku Umar \\ Email:eza.aulia88@gmail.com
}

\begin{abstract}
The main problem in this study is whether the system of internal supervision within the Court can realize the independence of judges and whether the constitutional Judge MK can be monitored externally. Constitutional Court Regulation No. 2 Year 2014 About the Honorary Council of the Constitutional Court can not guarantee the realization of the independence of the Constitutional Court, it can be seen from the supervisory role of the Board of Ethics that is passively waiting for reports from the public in the event of violations committed by the Constitutional Court, then the authority and composition both the membership of the Board of Ethics and the Court of Honor Assembly that require improvement, so ensuring the neutrality and mutual balance between the elements contained in the Board of Ethics and the Council of Honor Court. It is recommended that the Court made improvements with respect to the internal control system by means of amending the Constitutional Court Regulation No. 2 of 2014. It should be carried out a review of the elements of the membership of the Board of Ethics and Honor Council and the authority of the institution so that it can more leverage in carrying out its functions, that the surveillance system is applied can be realized a guarantee for the independence of the Constitutional Court.
\end{abstract}

Keywords: Monitoring System, Constitutional Justice, Independence of Judges, Constitutional Court. 


\section{PENDAHULUAN}

Pasal 24 UUD 1945, berbunyi; kekuasaan kehakiman merupakan kekuasaan yang merdeka untuk menyelenggarakan peradilan guna menegakkan hukum dan keadilan. Pasal 24 UUD 1945 menjamin kemerdekaan yang dimiliki oleh lembaga yudikatif, pada penelitian ini dikhususkan kepada lembaga MK. Penerapan teori pemisahan kekuasaan adalah untuk tetap menjamin kemerdekaan lembaga yudikatif dalam menjalankan fungsinya, di mana kemerdekaan tersebut diatur secara tegas oleh pasal 24 UUD 1945. Ide pokok tentang pemikiran pemisahan kekuasaan bermula pada pemikiran Montesquieu, bahwa suatu pemerintahan memiliki tiga keuasaan, yaitu formulasi (membuat undang-undang), kekuasaan pelaksana undang-undang, dan kekuasaan mengadili sesuai dengan undang-undang (Munir Fuady, 2011).

Mahkamah Konstitusi (MK) merupakan salah satu lembaga pemegang kekuasaan yudikatif yang memiliki kewenangan dan tanggungjawab dalam memberikan keadilan secara konstitusional kepada masyarakat. Oleh karena itu independensi dari para hakim selaku pelaksana kekuasaan yudikatif haruslah terjamin. Salah satu cara untuk mewujudkan independensi Hakim Konstitusi adalah melalui penerapan sistem pengawasan yang baik guna menegakkan kode etik dan perilaku hakim, mengingat beberapa peristiwa yang menghancurkan kewibawaan dan martabat MK berkaitan dengan permasalahan independensi hakim seperti dengan kejadian Surat Palsu MK terkait perolehan suara caleg Dapil I Sulawesi Selatan, pemerasan terhadap yang melibatkan bawahan dan anak dari hakim Arsyad Sanusi terhadap Dirwan Mahmud yang merupakan Calon Bupati Bengkulu Selatan yang didiskualifikasi oleh MK, kemudian peristiwa tertangkap tangannya Ketua MK Akil Mochtar oleh KPK.

Berdasarkan uraian yang telah disampaikan sebelumnya, berbagai persoalan menyangkut independensi Hakim Konstitusi, serta menyangkut landasan hukum sistem pengawasan yang diterapkan pada MK. Hal terpenting yang harus dicermati adalah berkenaan dengan sistem pengawasan Hakim Konstitusi guna mewujudkan independensi terhadap Hakim Konstitusi agar tegaknya salah satu pilar dari negara hukum yaitu peradilan yang bebas dan tidak memihak.

\section{METODE PENELITIAN}

Penelitian ini merupakan penelitian hukum yang bersifat normatif. Adapun penelitian ini merupakan penelitian yang berbentuk preskriptif, yaitu penelitian yang ditujukan untuk mendapatkan saran-saran mengenai apa yang harus dilakukan guna mengatasi masalah (Soerjono Soekanto, 1986). Pendekatan penelitian yang digunakan meliputi pendekatan azas dan pendekatan perbandingan. Jenis data yang digunakan pada penelitian ini adalah data sekunder. Sumber data sekunder yang digunakan mencakup bahan hukum primer, bahan hukum sekunder, dan bahan hukum tersier. Penelitian ini juga menggunakan data primer yang didapat dari hasil wawancara dengan narasumber.

Teknik pengumpulan data yang digunakan berupa bahan pustaka melalui dokumen resmi (putusan), buku-buku literatur, peraturan perundang - undangan, serta pengumpulan data melalui media elektronik yang berhubungan dengan masalah yang diteliti. Analisa yang digunakan dalam penelitian ini adalah deksriptif kualitatif, yaitu menganalisis data yang ada untuk selanjutnya dikaji dan diinterpretasikan oleh peneliti untuk mendapatkan kesimpulan yang diharapkan.

\section{HASIL DAN PEMBAHASAN}

\section{Teori pengawasan dan independensi Hakim}

Secara etimologi pengawasan menurut Anton M Moeliono dalam Irfan fachruddin (2004), kata pengawasan berasal dari kata "awas", yang berarti "penjagaan" dikenal dalam ilmu manajemen dan ilmu administrasi sebagai salah satu unsur dalam kegiatan pengelolaan.Hal senada disampaikan pula oleh Victor M Simamorang\& Jusuf Juhir (1994) yang menyatakan 
pengawasan diuraikan dari segi tata bahasa berasal dari kata "awas", sehingga pengawasan diartikan kegiatan mengawasi saja, dalam arti melihat sesuatu dengan seksama. George R. Tery dalam Irfan fachruddin (2004)menggunakan istilah "control" dalam mendefinisikan pengawasan, sebagaimana dikutip oleh Muchsan "control is to determine what is accomplished, evaluate it, and apply corrective, measures, if needed to ensure result in keeping with the plan".

Pengawasan adalah setiap usaha dan tindakan dalam rangka untuk mengetahui sejauh mana pelaksanaan tugas yang melaksanakan menurut ketentuan dan sasaran yang hendak dicapai(Situmorang\& Jusuf Juhir, 1994). Menurut Slamet Rudianto (2006) menyatakan pengawasan di bagi atas 2 bagian, iaitu:

1. Menggambarkan wujud dari kegiatan pengawasan.

2. Menggambarkan tujuan dan sasaran yang hendak dicapai oleh pengawasan itu sendiri. Apabila dicermati secara mendalam, pengertian pengawasan meliputi:

1. Pengawasan ditujukan sebagai upaya pengelolaan untuk mencapai hasil dan tujuan;

2. Adanya tolak ukur yang dihasilkan sebagai acuan keberhasilan;

3. Adanya kegiatan mencocokkan antara hasil yang dicapai dengan tolak ukur yang ditetapkan;

4. Mencegah terjadinya kekeliruan dan menunjukkan cara serta tujuan yang benar;

5. Adanya tindakan koreksi apabila hasil yang dicapai tidak sesuai dengan tolak ukur yang dipakai(Isrok, 2009).

Donnelly, et.al (1994) mengelompokkan pengawasan menjadi 3 (tiga) tipe dasar, yaitu:

1. Pengawasan pendahuluan (preliminary control), pengawasan ini dilakukan dengan memusatkan perhatian pada masalah mencegah timbulnya deviasi-deviasi pada kualitas serta kuantitas sumber-sumber daya yang digunakan pada organisasi-organisasi.

2. Pengawasan pada saat pekerjaan berlangsung (concurrent control), pengawasan yang dilakukan dengan memonitor pekerjaan yang berlangsung guna memastikan bahwa sasaran-sasaran telah dicapai.

3. Pengawasan feedback (feedback control), pengawasan yang dilakukan dengan memusatkan perhatian pada hasil akhir.

Pada pelaksanaanya, pengawasan terbagi-bagi dan diklasifikasikan kepada berbagai jenis, antara lain dikenal:

1. Pengawasan langsung

Pengawasan langsung adalah pengawasan yang dilakukan secara pribadi oleh pimpinan atau pengawas dengan mencermati, meneliti, memeriksa, mengecek sendiri secara langsung di tempat pekerjaan dan menerima laporan-laporan secara langsung pula dari pelaksana.

2. Pengawasan tidak langsung

Pengawasan tidak langsung diselenggarakan dengan mempelajari laporan-laporan yang diterima dari pelaksana baik lisan maupun tulisan, mempelajari pendapat-pendapat masyarakat dan sebagainya tanpa pengawasan di tempat dilakukannya pekerjaan(Stephen Robein, 1987).

Perspektif kelembagaan yang dikontrol dan yang melakukan kontrol, pengawasan dapat dibedakan menjadi:

1. Kontrol ekstern (external kontrol)

Kontrol ekstenal adalah pengawasan yang dilakukan oleh badan atau organ secara struktural organisasi berada diluar badan atau lembaga yang diawasi.

2. Kontrol intern (internal kontrol)

Kontrol internal adalah pengawasan yang dilakukan oleh suatu badan atau organ yang secara struktural masih termasuk organisasi dalam lingkungan badan atau lembaga yang diawasi (Irfan fachruddin, 2004) 
Ditinjau dari sudut pandang waktu pengawasan, pengawasan dapat dibedakan menjadi:

1. Kontrol apriori

Kontrol apriori adalah pengawasan yang dilakukan sebelum dilakukannya suatu tindakan, kontrol ini mengandung unsur pengawasan preventif yaitu untuk mencegah atau menghindari terjadinya kekeliruan.

2. Kontrol a-posteriori

kontrol a-posteriori adalah pengawasan yang dilakukan sesudah dilakukannya suatu tindakan (Irfan fachruddin, 2004 : 93). menjelaskan:

Sujamto (1986) dalam bukunya "Beberapa Pengertian di Bidang Pengawasan",

1. Pengawasan preventif

Pengawasan Preventif adalah pengawasan yang dilakukan sebelum pelaksanaan, yakni pengawasan yang dilakukan terhadap suatu yang bersifat rencana.

2. Pengawasan represif

Pegawasan represif merupakan pengawasan yang dilakukan setelah pekerjaan atau kegiatan dilaksanakan. Dapat pula dikatakan bahwa pengawasan represif sebagai salah satu bentuk pengawasan atas ajalannya pemerintahan.

Ditinjau dari objek pengawasan, pengawasan terbagi atas:

1. Pengawasan administratif

Pengawasan administratif yaitu pengawasan dilaksanakan dibidang yang fungsinya dikategorikan sebagai tugas admnistratif.

2. Pengawasan operatif

Pengawasan operatif adalah pengawasan yang dilaksanakan pada bidang yang berfungsi melaksanakan pekerjaan operatif.

Dipandang dari aspek yang diawasi, pengawasan dapat dibedakan kepada

1. Pengawasan segi hukum (legalitas)

Pengawasan segi hukum adalah pengawasan yang dimaksudkan untuk menilai segi-segi hukum saja (rechtmatigheid).

2. Pengawasan segi kemanfaatan (oppurtunitas)

Pengawasan segi kemanfaatan adalah pengawasan yang dilakukan untuk menilai segi kemanfaatannya (dogmatigheid)(Irfan fachruddin, 2004).

Dipandang dari cara pengawasan, pengawasan dibedakan kepada:

1. Pengawasan negatif represif

Pengawasan negatif represif adalah pengawasan yang dilakukan setelah suatu tindakan dilakukan.

2. Pengawasan negatif preventif

Pengawasan negatif prefentif adalah pengawasan yang dilakukan oleh badan yang lebih tinggi kepada badan yang lebih rendah untuk menghalangi terjadinya kelalaian(Irfan fachruddin, 2004).

Secara umum dapat dikemukakan ada dua prinsip yang biasa dipandang sangat pokok dalam sistem peradilan, yaitu:

1. The principle of judicial independence

Prinsip independensi antara lain harus diwujudkan dalam sikap hakim dalam sikap hakim memutuskan dan memutus perkara yang dihadapinya, disamping itu independensi juga tercermin dalam berbagai pengaturan mengenai hal-hal yang berkaitan dengan pengangkatan, masa kerja, pengembangan karir, sistem penggajian, dan pemberhentian para hakim.

2. The principle of judicial impartiality 
Prinsip ketidakberpihakan adalah mengandung makna dibutuhkannya hakim yang tidak saja bekerja secara imparsial (to be impartial), tetapi juga terlihat bekerja secara imparsial (to appear be impartial) (Jimly Asshiddiqie, 2005).

Independensi hakim dan pengadilan terwujud dalam kemerdekaan hakim. Baik secara sendiri-sendiri maupun sebagai institusi, dari berbagai pengaruh yang berasal dari luar diri hakim berupa intervensi yang bersifat mempengaruhi secara langsung berupa bujuk rayu, tekanan, paksaan ancaman, atau tindakan balasan karena kepentingan politik atau ekonomi tertentu dari pemerintah atau kekuatan politik yang berkuasa, kelompok atau golongan tertentu, dengan imbalan atau janji imbalan berupa keuntungan jabatan, keuntungan ekonomi atau bentuk lainnya(Titik Triwulan Tutik, 2012).

Faisal A. Rani (2009) menyebutkan bahwa bahwa kemerdekaan kekuasaan kehakiman juga tidak akan tercipta apabila para hakim berada dalam ikatan-ikatan loyalitas, baik dalam ikatan secara pribadi, maupun dalam ikatan kelompok. Dalam kaitan tersebut Richard D.Aldrich (Faisal A. Rani, 2009) mengatakan bahwa kemerdekaan kekuasaan kehakiman berarti: "...bahwa para hakim tersendiri harus tetap bebas dari pengaruh, kecuali atas perintah hukum, konstitusi, keputusan yang dipertimbangkan pemikiran sehat, preseden hukum, dan perintah hati nurani hakim sendiri".

Sirajudin menyatakan ada 3 faktor utama yang mempengaruhi munculnya mafia peradilan, yang tentunya berhubungan dengan independensi hakim, antara lain:

1. Menyangkut sistem rekruitmen aparat peradilan yang masih menunjukkan adanya praktek kolusi, korupsi dan nepotisme (KKN) yang pada akhirnya melahirkan aparat yang tidak berkompeten, baik dari segi hardskill maupun softskill.

2. Menyangkut masalah transparansi pelayanan umum dan administrasi peradilan, maslah ini penting bagi masyarakat pencari keadilan, seperti menyangkut kejelasan berapa lama suatu perkara seharusnya diproses, berapa biaya yang dibutuhkan, serta bagaimana mekanismenya.

3. Lemahnya sistem pengawasan dan penindakan (Sirajuddin, dkk, 2007).

\section{Analisis Terhadap sistem pengawasan Internal MK}

Sistem pengawasan yang dibangun melalui Peraturan MK Nomor 2 Tahun 2014, diawali dengan terlaksananya suatu pengawasan informal melalui peran masyarakat baik perorangan, kelompok, maupun lembaga selaku pelaksana kontrol sosial. Masyarakat dalam hal ini berperan sebagai pelapor, kemudian laporan yang disampaikan oleh masyarakat tersebut diteruskan oleh Dewan Etik dan diselesaikan dengan menggunakan mekanisme internal lembaga. Terhadap sistem pengawasan yang demikian, menurut hemat penulis merupakan suatu sistem pengawasan yang sangat longgar, di mana Dewan Etik selaku perangkat yang dibentuk oleh MK bertujuan untuk menjaga dan menegakkan kehormatan, keluhuran martabat dan kode etik hakim konstitusi bersifat pasif, karena hanya dapat memproses suatu dugaan pelanggaran atas dasar pelaporan dari masyarakat.

Pengawasan yang dilakukan oleh Dewan Etik merupakan pengawasan formal dalam lingkup internal yang bersifat pasif, dari segi waktu dikategorikan sebagai pengawasan aposteriori yang mengandung unsur represif atau terlaksana setelah terjadinya suatu perbuatan. Pengawasan yang bersifat pasif tersebut dirasa kurang tepat, mengingat Dewan Etik berada dilingkungan internal lembaga $\mathrm{MK}$, baru dapat mengambil suatu tindakan berdasarkan kewenangannya setelah terjadinya suatu pelanggaran yang dilakukan oleh Hakim Konstitusiatas pelaporan dari masyarakat.

Penulis berpendapat, mengingat MK tidak diawasi oleh lembaga yang memiliki kewenangan bersifat formal, seperti Komisi Yudisial yang secara eksternal mengawasi para Hakim Agung dan hakim-hakim pada peradilan dibawahnya. Sudah sepatutnya pengawasan yang dimiliki oleh Dewan Etik juga bersifat aktif, dalam artian tidak hanya menunggu laporan 
masyarakat yang berasal dari luar kelembagaan, akan tetapi juga dapat langsung mengawasi segala perilaku hakim di dalam lembaga dan dapat melakukan tindakan apabila terjadi pelanggaran terhadap perilaku maupun kode etik yang mereka temukan di internal lembaga tanpa harus menunggu pelaporan dari masyarakat, hal tersebut merupakan suatu pertimbangan mengingat Dewan Etik berkantor di MK, menjadi suatu keuntungan melakukan pengawasan langsung terhadap perilaku dari hakim konstitusi di lingkungan internal kelembagaan. Hal demikian tentunya menjadikan Dewan Etik sebagai early warning sytem dalam lingkungan internal MK.

Pembenahan selanjutnya adalah menyangkut mekanisme pemilihan calon anggota Dewan Etik yang dilakukan oleh Panitia Seleksi bersifat independen yang dipilih melalui rapat pleno hakim bersifat tertutup, di mana Panitia Seleksi berjumlah 3 (tiga) orang, yang terdiri dari 1 (satu) orang mantan Hakim Konstitusi, 1 (satu) orang akademisi, dan 1 (satu) orang tokoh masyarakat. Penulis berpendapat bahwa setiap unsur yang terdapat dalam Panitia Seleksi adalah berasal dari lingkungan yang sama dengan unsur yang terdapat dalam Dewan Etik, sehingga dengan pertimbangan bahwa Dewan Etik merupakan perangkat yang bersifat tetap, maka unsur yang terdapat di dalamnya haruslah berasal dari unsur yang memiliki pemahaman yang baik tentang lembaga peradilan. Oleh karena itu dirasa lebih tepat jika unsur tokoh masyarakat pada Panitia Seleksi digantikan dengan 1 (satu) orang mantan Hakim Agung. Unsur yang berasal dari tokoh masyarakat memiliki pemaknaan yang sangat luas dan universal, mengingat definisi ketokohan seseorang di dalam masyarakat, indikator ketokohan seseorang di dalam masyarakat dan komunitas masyarakat seperti apa yang menokohkan seseorang tersebut. Walaupun pada kenyataannya selama ini unsur tokoh masyarakat di isi oleh orang yang berasal dari dunia akademisi.

Berdasarkan alasan tersebut, maka lebih tepat jika unsur tokoh masyarakat diisi oleh seorang mantan Hakim Agung yang notabene memiliki pengalaman dan pemahaman yang tentunya mendalam tentang seluk beluk dari lembaga peradilan. Karena perubahan unsur tersebut berdampak pula pada komposisi Dewan Etik yang juga otomatis berubah mengingat unsur pada Panitia Seleksi merupakan Unsur yang sama Dengan Dewan Etik. Atas perubahan tersebut maka komposisi Dewan Etik nantinya juga akan berubah menjadi 1 (satu) orang mantan Hakim Konstitusi, 1 (satu) orang Guru Besar dalam bidang ilmu hukum, dan 1 (satu) orang mantan Hakim Agung.

Pertimbangan yang penulis berikan berkenaan dengan komposisi Dewan Etik seperti yang telah dijelaskan, adalah bahwa ketiga unsur baik mantan Hakim Konstitusi, Guru Besar dalam bidang ilmu Hukum dan mantan Hakim Agung merupakan unsur-unsur yang tentunya memiliki pemahaman yang baik tentang seluk beluk lembaga peradilan dan mengerti tentang persoalan penegakan kode etik serta perilaku Hakim.

Hal terpenting adalah unsur-unsur tersebut juga mengerti betul hal-hal yang dapat dilakukan Dewan Etik dalam menjalankan tugasnya, terdapat batasan dalam hal pengawasan yang dilakukan tidak boleh menjadi suatu tekanan yang mengintervensi hakim sehingga merusak kemerdekaan ataupun independensi yang harus dimiliki oleh Hakim dalam menjalankan tanggungjawabnya selaku pelaksana kekuasaan kehakiman.

Terhadap komposisi Dewan Etik yang telah penulis rancang, diharapkan dengan pengalaman dan pemahaman yang dimiliki oleh ketiga unsur tersebut tentang lembaga peradilan, sehingga dapat terlaksananya suatu pengawasan yang tidak melanggar kemerdekaan atau independensi yang dimiliki oleh hakim dalam menjalankan tugasnya. Jadi pengawasan yang dilakukan oleh Dewan Etik, adalah pengawasan dalam rangka penegakan kode etik dan perilaku hakim yang menjunjung tinggi kemerdekaan/independensi, sehingga pengawasan yang dibangun dapat menciptakan independensi bagi Hakim dilingkungan MK.

Selanjutnya penulis melakukan koreksi menyangkut kewenangan yang dimiliki oleh Dewan Etik, berdasarkan Pasal 22 huruf c Peraturan MK Nomor 2 Tahun 2014, berbunyi: 
"Dewan Etik mengusulkan pembentukan Majelis Kehormatan untuk memeriksa dan mengambil keputusan terhadap Hakim Terlapor atau Hakim Terduga yang diduga melakukan pelanggaran berat...". Terhadap hal tersebut peran Dewan Etik hanya sebatas mengusulkan pembentukan Majelis Kehormatan saja, sedangkan pemilihan keanggotaan Majelis Kehormatan sesuai dengan Pasal 6 ayat (1), (2), dan (3) kesemuanya melalui campur tangan dari MK secara penuh dalam hal pemilihannya.

Menurut penulis, hal tersebut dirasa kurang tepat, dikarenakan adanya suatu kekhawatiran terhadap objektivitas atau kenetralan terhadap para Hakim Konstitusi yang memilih anggota Majelis Kehormatan. Tidak dapat dipungkiri kekhawatiran yang dimaksud adalah terdapat hubungan emosional baik kedekatan dalam pergaulan sehari-hari, perasaan sesama profesi atau semangat membela kelembagaan yang terdapat antara para Hakim Konstitusi dengan Hakim yang diduga melakukan pelanggaran berat.

Walaupun terdapat kemungkinan yang kecil terhadap kekhawatiran yang penulis utarakan mengingat profesionalitas dari para Hakim Konstitusi, namun akan lebih tepat jika calon anggota Majelis Kehormtan ditentukan dalam rapat pleno hakim yang bersifat tertutup dengan melibatkan Dewan Etik. Hal tersebut dilakukan sebagai jaminan terhadap netralitas para hakim dalam menentukan calon anggota Majelis Kehormatan. Terhadap hal tersebut maka Dewan Etik memiliki kewenangan selain mengusulkan pembentukan Majelis Kehormatan, juga menentukan calon anggota Majelis Kehormatan bersama-sama dengan Hakim Konstitusi dalam rapat pleno hakim yang bersifat tertutup.

Koreksi lain yang dilakukan untuk menyempurnakan sistem pengawasan internal MK adalah pada keanggotaan atau komposisi Majelis Kehormatan yang menurut penulis lebih tepat ditentukan oleh para hakim dalam rapat tertutup bersama dengan Dewan Etik seperti yang telah diutarakan sebelumnya. Komposisi keanggotaan Majelis Kehormatan menurut Peraturan MK Nomor 2 Tahun 2014 adalah berjumlah 5 (lima) orang, terdiri dari 1 (satu) orang Hakim Konstitusi, 1 (satu) orang anggota Komisi Yudisial, 1 (satu) orang mantan Hakim Konstitusi, 1 (satu) orang Guru Besar dalam bidang ilmu hukum, dan 1 (satu) orang tokoh masyarakat.

Menurut hemat penulis komposisi keanggotaan Majelis Kehormatan berdasarkan Peraturan MKNomor 2 Tahun 2014 perlu dilakukan koreksi, mengingat unsur yang terdapat pada Dewan Etik terdapat pula pada Majelis Kehormatan. Penulis berpendapat pembentukan Majelis Kehormatan yang dibentuk dengan beberapa komposisi yang sama dengan Dewan Etik akan tetapi diisi dengan pengusulan yang baru tidaklah tepat, hal tersebut berimbas kepada terjadi pengulangan terhadap proses pemeriksaan pendahuluan, dikarenakan kewenangan Majelis Kehormatan dijalankan oleh unsur yang sama dengan Dewan Etik tetapi oleh orang yang berbeda. Keadaan yang terjadi adalah Majelis Kehormatan akan melakukan pengumpulan informasi ulang terhadap bukti-bukti yang telah di dapat oleh Dewan Etik, serta memintai keterangan kepada dewan Etik dan Hakim Terduga melakukan pelanggaran. Hal tersebut tentunya merupakan suatu pengulangan rangkaian proses pemeriksaan, di mana seharusnya pemeriksaan pendahuluan yang dilakukan tidak lagi mengulang proses pemeriksaan yang telah dilakukan oleh Dewan Etik, tetapi lebih kepada melanjutkan proses berupa pendalaman terhadap materi-materi yang yang telah dihimpun oleh Dewan Etik serta keterangan dari Hakim Terlapor agar proses pemeriksaan dapat berjalan dengan lebih efisien dari segi waktu.

Agar terlaksananya keadaan yang efesien dari segi waktu, maka penulis berpendapat anggota Dewan Etik sepatutnya adalah ex officiodari Majelis Kehormatan. Hal tersebut melihat secara keanggotaan terdapat kesamaan unsur pada komposisi keduanya, sehingga tidak perlu dilakukan pencalonan ulang dalam Majelis Kehormatan. Kemudian agar terwujudnya netralitas dan saling mengimbangi antara unsur-unsur yang terdapat dalam Majelis Kehormatan, dilakukan pemilihan terhadap anggota Majelis Kehormatan yang bukan ex officioDewan Etik dalam rapat pleno hakim yang bersifat tertutup bersama dengan Dewan Etik. 
Penulis berpendapat agar terjaminnya netralitas dan saling mengimbangi antara unsurunsur yang terdapat dalam Majelis Kehormatan perlu ditambahkan 4 (empat) unsur baru yang bukan ex officioDewan Etik. Keempat unsur tersebut antara lain: 1 (satu) orang anggota Komisi Yudisial yang ditugaskan oleh Komisi Yudisial atas permintaan MK, kemudian 3 (tiga) unsur lainnya dipilih dalam rapat pleno hakim yang bersifat tertutup bersama dengan Dewan Etik. 3 (tiga) unsur yang dimaksud adalah: 1 (satu) orang hakim konstitusi, 1 (satu) orang pengacara senior yang telah selama kurun waktu 3 (tiga) tahun tidak beracara di MK baik secara individu maupun mewakili kelembagaan firma hukum tertentu atau firma hukum miliknya sendiri, dan 1 (satu) orang tokoh masyarakat.

Komposisi keanggotaan Majelis Kehormatan yang disusun oleh penulis terdiri dari 7 (tujuh) orang yang mewakili unsur yang berbeda, serta dengan cara pengisian yang berbeda. Cara pengisian pertama adalah melalu keanggotan Dewan Etik secara ex officioMajelis Kehormatan yang terdiri dari : 1 (satu) orang mantan Hakim Konstitusi, 1 (satu) orang Guru Besar dibidang ilmu hukum, dan 1 (satu) orang mantan Hakim Agung. Kemudian pengisian kedua adalah melalui pimilihan pada rapat pleno hakim yang bersifat tertutup bersama dengan Dewan Etik, terdiri dari: 1 (satu) orang hakim konstitusi, 1 (satu) orang pengacara senior, dan (1) orang tokoh masyarakat. Pengisian ketiga adalah penugasan 1 (satu) orang anggota Komisi Yudisial oleh Komisi Yudisial atas permintaan dari MK.

Komposisi keanggotaaan Majelis Kehormatan yang telah penulis rancang, merupakan komposisi yang menurut penulis saling mengimbangi antara unsur yang ada di dalamnya sehingga dapat terjaga netralitas dari majelis tersebut, maksud saling mengimbangi dari keanggotaan adalah setiap unsur keanggotaan dapat mengimbangin unsur lainnya, dapat dicontohkan unsur mantan hakim konstitusi diimbangi oleh unsur mantan hakim agung, unsur hakim konstitusi diimbangi oleh unsur dari Komisi Yudisial, dan unsur Pengacara Senior yang berasal dari kalangan praktisi diimbangi oleh unsur Guru Besar dalam bidang ilmu hukum yang berasal dari kalangan akademisi, serta untuk menyempurkan komposisi keanggotaan tersebut dipilih seorang tokoh masyarakat untuk menjamin netralitas dari Majelis yang dibentuk, sehingga sistem pengawasan yang ada berikut dengan mekanisme penegakan kode etik dan perilaku hakim dilingkungan konstitusi benar-benar dapat mewujudkan independensi dari Hakim Konstitusi. Untuk menjawab rumusan masalah pada penelitian ini, berdasarkan pemaparan sebelumnya penulis berpendapat bahwa pengawasan internal yang ada dilingkungan MK masih memiliki banyak kekurangan, sehingga belum menjamin terciptanya independensi Hakim di lingkungan MK. Oleh karena itu, perlu dilakukan beberapa perbaikan agar dapat terwujudnya independensi dari Hakim Konstitusi. Perbaikan yang dimaksud adalah seperti yang telah dijelaskan sebelumnya.

\section{SIMPULAN DAN SARAN}

A. Simpulan

1. Pengawasan internal terhadap MK yang ada saat ini sebagaimana diatur dalam Peraturan MK Nomor 2 Tahun 2014 Tentang Majelis Kehormatan MK, masih memiliki beberapa kekurangan seperti kewenangan pengawasan yang dimiliki oleh Dewan Etik bersifat pasif, hal tersebut dirasa sangatlah longgar mengingat peran Dewan Etik sebagai early warning system, dan keberadaan Dewan Etik yang berada dilingkungan Internal MK.

2. Dewan Etik mengusulkan pembentukan Majelis Kehormatan MK, yang kemudian MK melakukan pemilihan terhadap keanggotaan Majelis Kehormatan, hal tersebut juga dirasa kurang tepat, berkenaan dengan keadaan MK membentuk suatu Majelis yang dipilih oleh dirinya sendiri untuk mengawasai dan melakukan penegakan terhadap dirinya sendiri. Terkait dengan pembentukan Majelis Kehormatan, dilihat perlu adanya penyempurnaan komposisi keanggotaan pada Majelis Kehormatan, dengan melihat bahwa terdapat unsur yang sama antara Dewan Etik dan Majelis Kehormatan. 


\section{B. Saran}

1. Disarankan agar adanya penyempurnaan berkenaan dengan sistem pengawasan internal dilingkungan MK dengan melakukan perubahan terhadap Peraturan MK Nomor 2 Tahun 2014 Tentang Majelis Kehormatan MK. Perubahan yang dimaksud berkenaan dengan unsur keanggotaan Dewan Etik yang harus ditinjau ulang, kewenangan Dewan Etik dan terhadap tugas pengawasan yang diemban oleh Dewan Etik haruslah bersifat aktif.

2. Disaran agar unsur keanggotaan pada Majelis Kehormatan diperlukan beberapa perubahan mekanisme pengisian keanggotaaan dan penambahan unsur keanggotaan agar terciptanya perimbangan unsur, sehingga dapat lebih baik menjalankan tugas dalam rangka menjaga dan menegakkan kehormatan, keluhuran martabat, serta perilaku dari Hakim Konstitusi.

\section{REFERENSI}

Donnelly, James H., Gibson, James L., and Ivancevich, John. 1994. Fundamental of Management. Texas. Business Publication.

Faisal A. Rani.2009. Fungsi Dan Kedudukan Mahkamah Agung Sebagai Penyelenggara Kekausaan Kehakiman Yang Merdeka Sesuai Dengan Paham Negara Hukum.Banda Aceh. Syiah Kuala University Press.

Irfan Fachruddin. 2004.Pengawasan Peradilan Administrasi Terhadap Tindakan Pemerintah. Bandung. Alumni.

Isrok. 2009. Korelasi antara Peraturan Daerah (PERDA) Bermasalah Dengan Tingkat Investasi Ke Daerah. Jurnal Hukum No. 4 Vol.

Jimly Asshiddiqie. 2006.Pengantar Ilmu Hukum Tata Negara Jilid II. Jakarta. Sekretariat Jenderal dan Kepaniteraan MK RI.

Munir Fuadi. 2011.Teori Negara Hukum Modern (Rechtstaat). Bandung. PT Refika Aditama.

Sirajuddin, Zulkarnain dan Sugianto. 2007. Komisi Pengawas Penegak Hukum: Mampukah Membawa Perubahan. Malang. Malang Coruption Watch (MCW)-YAPPIKA.

Slamet Rudianto. 2006.Tinjauan Hukum Mengenai Pengawasan Penyelenggaraan Telekomunikasi Siaran Analog Pada Pita Ultra Hight Frequency (UHF) Bagi Kanal Transmisi Televisi Digital. Skripsi,Universitas Komputer Indonesia.

Soerjono Soekanto. 1986.Pengantar Penelitian Hukum.Jakarta. UI-Press.

Stephen Robein. 1987.The Administration Process. New Delhi. Prentice Hall of India Private Ltd.

Sujamto. 1986. Beberapa Pengertian di Bidang Pengawasan. Jakarta. Ghalia Indonesia.

Titik Triwulan Tutik. 2012. Pengawasan Hakim Konstitusi Dalam Sistem Pengawasan Hakim Menurut UUD 1945. Jurnal Dinamika Hukum Vol. 12 No. 2.

Victor M Situmorang \& Jusuf Juhir.Aspek Hukum Pengawasan Melekat Dalam Lingkungan aparatur Pemerintahan. Jakarta. Rineka Cipta.

Undang-Undang Dasar Negara Republik Indonesia Tahun 1945. (Amandemen ke 4) 